\title{
Stability and the Law
}

\section{Susan Trevaskes, Elisa Nesossi, Flora Sapio, Sarah Biddulph}

\section{Introduction}

This book is about judicial and governmental activism around the issue of managing social instability in China today. The studies in this volume examine the relationship between law and politics and observe how the stability imperative shapes this interaction.

In official circles in China, social stability is generally understood to mean the sense of political and social security that accompanies orderly and non-conflictual social relations. The maintenance of stability has become a defining socio-political goal because the Chinese Party-state sees social disorder as a threat to the future prospects for economic growth and therefore to its own future. Instability is manifest in what the Communist Party-state deems disharmonious relations within communities and between individuals and the state brought about by crime, disputes and protest. How local courts and governments marshal the forces of law to prevent and punish crime, resolve disputes and to manage protest has become a central socio-political concern for China's governing authorities.

The studies in this book reach across various areas of the legal system in China including litigation and mediation practices, substantive and procedural law reform, the operations of parapolicing and detention centres, anti-corruption initiatives and administrative law. Running through these studies are two related threads. The first concerns how the imperative of social stability has reframed official approaches to law and justice in the decade of the 2000s. The second relates to the challenges posed to the legitimacy of the law when the stability agenda overtakes routine law and justice 
concerns. The authors of this book show that when stability trumps all other concerns, those who administer justice find it hard to balance the imperatives of crime control and due process; those who adjudicate civil and criminal cases find it difficult to reconcile the requirement to achieve positive legal outcomes and positive social outcomes; and those in government and courts who deal with labour, land and environmental disputes find it difficult to 'harmonise' competing rights and interests of the participants, especially when one of the parties in a dispute is a local government agency. These studies demonstrate that the stability imperative has come to challenge law's legitimacy in the eyes of many because of the way in which it hampers the ability of judges and government decisionmakers to follow established legal procedure. More to the point, it dilutes their capacity to make judicial and governmental decisions free from the political pressure to maintain stability. The stability imperative has compelled the Party-state to reframe legal and justice practices in a way that in many respects, run counter to the Party's own principle of 'governing the country according to the law' (yifa zhiguo).

Containing instability at the local levelSince Deng's era of open reform began, stability has been conceived by the Party-state as a precondition of successful economic development (Dutton 1992). Given its prerequisite status, most of China's criminal justice policies of the past 30 years have been formulated with social stability as their legitimising basis (Biddulph 2007; Trevaskes 2010). Though a key political preoccupation since after the Tiananmen in 1989 , it took until the early years of the $21^{\text {st }}$ century for this concern to be fully institutionalised in the justice and security arenas. Over the last 15 years or more, the stability concern has widened considerably to incorporate social actions that now reach well beyond criminal activities to include legal disputes, individual petitioning and collective protests.

The Chinese Communist Party (CCP) generally characterises high levels of instability in terms of the number of petitions (xingfang, that is, 'letters and visits' to courts and government offices by aggrieved individuals) and 'mass incidents' (qunti shijian, that is, public protests) in local areas. Most individual and collective protests 
concern civil disputes, mainly government decisions or court decisions about land, labour or environmental issues. To a lesser extent, they concern outcomes of criminal cases. Even before the Central Party Committee (CPC) called for all social and public institutions to deal with the stability problem by building a 'Harmonious Society' in 2004, the CPC had begun commissioning internal reports on the state of instability, soliciting internal policing opinion about the actual extent of threat that mass incidents pose to China's stability. A national research grant funded by the CPC in 2002, drew up a national 'state of play' on the impact of mass incidents on stability. In their report on the state of mass incidents in 2002 to 2003 titled "Research Report on Mass Incidents" (Chen 2004) the researchers surmised that mass incidents pose a direct threat to the government and $\mathrm{CCP}^{\prime} \mathrm{s}$ image, to the authority of the law, to political stability and to community respect for 'social order'. Earlier internal reports on the state of instability had come to the conclusions that mass incidents lead to a dramatic lose of community trust in the state, pitting those who manage society (guanlizhe) against those in society who are managed (bei guanli de), further escalating antagonism between state and society (Yang, 2002).

During the last decade, stability has become the primary socio-political concern of the Party-state, which claims that unregulated social action such as protest or legal dispute over socially-sensitive matters such as land, labour and environmental issues threatens not only the success of China's economic agenda but also the nation's political life and the Party's future. This preoccupation with stability has reshaped the Partystate's approaches to justice, to government decision-making practices and security arrangements. The overriding concern is containment of potential or realised unrest and dissent at the local level so that a social problem or dispute does not escalate to become unmanageable.

Local courts and governments have therefore become increasingly 'activist' (Zhu 2010 ) in their decision-making in response to the escalating number of people who use 
the mode of petitioning outside court and government agencies to seek justice. Since many protestors and petitioners perceive that they are unable to find justice in their local courts, over the last 15 years or so, millions of petitioners have travelled to provincial capitals or Beijing to lodge protests in the hope of having court or government decisions overturned. Particularly in the early to mid-2000s, complainants preferred to take their chances petitioning in Beijing or in the provinces since they find it difficult to have their grievances heard in local courts or by the local government (Zhang 2009; Li, Liu and O'Brien 2012). In response to the petitioning phenomenon and to the escalation in collective protests, central and provincial authorities have produced a strategy of 'localising grievances while insulating the Centre' (Mattis 2012). One aspect of this strategy involves policing protests financed through a 'Stability Maintenance' budget that now runs to over 700 billion yuan (approximately US $\$ 120$ billion) annually. Another aspect involves courts refusal of civil cases for litigation and increased emphasis on mediation (Woo 2013).

Mediation is attractive to local authorities because by the time the complainants have agreed to the terms of a mediation agreement, they are no longer able to legitimately complain through appeal against such a decision that they participated in. However, Beijing's pressuring of local courts to 'close the case and solve the problem' (anjie shiliao) (Liebman 2012; Zhang 2012) before it reaches higher levels of justice administration or before petitioners head off to Beijing to protest, has created a logistical problem for local authorities. With up to 80 percent of administrative cases are now required to undergo mediation rather than litigation (Zhou 2010; Wang 2013), court time is increasingly taken up with judicial mediation outside courtrooms.

\section{Citizen Activism, State Activism and Rights}

From the outset of China's open door reforms in the late 1970s with Deng Xiaoping at the national helm, the Party-state linked development of rights directly to its blueprint for economic modernisation. Economic and social rights were made the nation's top human 
rights priority, to be developed in lockstep with increasing national wealth. Official discourse linked commitment to improving rights to subsistence as the nation's primary human rights goal while the state gradually withdrew from what had been its responsibilities as 'provider' to enable the market to function. Subsistence was indeed still a critical problem for many Chinese in the 1980s and early 1990s.

The Chinese government's most impressive feat over the last two decades has been to lift out of poverty hundreds of millions of people from rural areas across the nation, an accomplishment of truly historic proportions. But the social and economic fallout of this feat has challenged many people's social and economic rights. Uneven distribution of wealth, unequal access to justice, and corruption-entrenched throughout a political system characterised by weak oversight mechanisms-have inspired widespread discontent. Many increasingly feel that their health, property and wages are no longer adequately protected by the legal system or government. They are aggrieved when local authorities consistently fail to punish widespread corruption. They are also aggrieved when government and courts protect the economic interests of big and small business over the rights and interests of the Chinese people. They want state action through law and policy to deliver justice by protecting their rights as citizens rather than their roles in what has become a political as well as economic marketplace. Citizens, like the state, have been increasingly activist and strategic about how they approach this activism (Chen 2012; Fu 2013).

The fallout of decades of social and economic inequality and inadequate access to reliable avenues of justice have therefore transformed the rights debate in China's liberal press (the Southern Daily and Southern Weekend) and in social media, which has shifted significantly to the issue of how protests, petitions, appeals and security threats are managed and punished. Crucially this fallout also creates challenges posed to the legitimacy of the law at times when the stability agenda overtakes routine law and justice concerns. At the core of the stability obsession is the issue of loss of public trust in the law (Minzner 2013; Chen 2013). Mass protests continue to occur because people have little faith in the commitment and ability of local governments to address their problem or 
local courts to deliver fair and independent decision-making, especially when courts refuse to accept socially-sensitive cases for litigation. While billions of yuan each year are poured into Stability Maintenance operations (Xie 2013), an additional and arguably more costly aspect to maintaining stability is apparent; it is the loss of regime legitimacy in the public's eyes brought about by changing legal and justice practices to accommodate the stability imperative. Authorities have been unwilling or unable to effectively address two key sources of public anger that fuels social unrest; the corruption and apathy towards corruption apparently entrenched at all levels of government, and the issue of access to formal justice, that is, the incapacity of many people to use and afford the legal system as an avenue through which their grievances can be addressed.

The stability imperative is legitimised through grand political narratives such as Hu Jintao's 'Harmonious Society'. In the same manner, the rights prescribed by the Partystate for citizens to appeal and protest a legal or governmental decision is fashioned by political values and social system that is a product of nearly 70 years of Party rule. Citizen's actions can challenge government and court decisions as long as these challenges are circumscribed by what the Party-state sees as regime-threatening. And while China's transition has indeed opened a wider space for popular expression over the past 30 years, the scope and nature of this space are intrinsically linked to how far the Party-state is willing to tolerate disunity.

This may not be surprising when we consider that in most modern states, the official position on human rights is tailored by how the state validates notions of rights and justice to accommodate the impact of its governance and social control policies. In China, validation comes in the form of the concept of 'mutuality of rights and duties'.

'Mutuality of rights and duties' which is a guiding human rights principle in China, accommodates stability-related policy since it implies that rights are inseparable from the duties prescribed by the Constitution and other laws. Stressing the utmost importance of 'social stability' serves to lock on rights to duties and in the process it interlocks the mutual responsibilities of citizen and state. Since the Party-state sees social 
instability as a threat to economic development and national prosperity, citizens who are not fulfilling their duty to maintain social stability so forfeit their rights. Official jurisprudence sees that individual as well as collective protests undermine the rights of the larger collective ('the people') since protests of any size hamper economic development and hence the capacity of all citizens to realise their economic and social rights.

Regardless of how official jurisprudence legitimates state responses to instability, socio-economic disputes relating to land, environmental and labour issues are finding expression in over a hundred thousand collective protests that occur across the nation annually (Mattis 2012). The obsession with instability therefore pushes and pulls citizens' calls for justice through the tight nexus between politics and law. But the problem of how the state prescribes rights and justice is complicated by the reality of weak oversight mechanisms at the local level that have encouraged widespread corruption, corporate malfeasance and consequently, public mistrust of the law. The people's lack of access to reliable avenues for redressing injustice has also exacerbated problems from the speed and depth of social change through economic development, especially the increasing wealth gap separating rich from poor. But rather than to address these gaps, the Party-state has cast the consequent sharp rise in social unrest and protests-rather than their roots causes-as the key problem. It has made 'social stability' the key principle to legitimise both changes in justice and security practices and how it exercises authority to govern the nation through this era of increasing social discord.

The chapters in this volume share a number of themes primarily concerned about how citizens respond to injustice and how in turn, justice and security organs have reorganized their practices in response. This book is divided into three parts. Part One largely concerns legal disputes and the government and judicial activist mechanisms that seek to contain any social fallout of disputes or dissent. Part Two explores the myriad legal mechanisms open to authorities in responding to what they perceive as instability and examines how laws and legal practices have changed in response to the stability 
imperative. Part Three reflects on the political logic of the stability imperative, discussing the discursive frameworks that support it, in particular, 'Harmonious Society', 'Stability Maintenance' and 'Social Management'.

\section{Part One: Managing disputes}

Law is the main mechanism for action used both by the Party-state and its citizens in the stability arena. As we have noted above, the imperative of social stability is politicallyconceived by the Party-state and while it responds to instability through a range of legal and governmental mechanisms, the law also provides avenues for redress for citizens. When citizens believe that either individuals, the state or private enterprises have done them an injustice, law can become an empowering instrument. Citizens have increasingly adopted legal action such as protesting and appealing court decisions to defend their rights and interests. Many have successfully used legal avenues including administrative and civil law suits to fight decisions made against their interests by land developers, construction companies, factories, plants and local governments. But when citizens push, the Party-state pushes back by readjusting governmental and judicial decision-making practices. As we find in this book, such a use of the law by citizens can have limited success when we consider the close bonds of financial, administrative and political dependence that link courts to local governments and that shape adjudication and mediation practices.

Part One is about how citizens push - and how courts and governments push back - in labour, land and environmental disputes. Collective and individual legal disputes began to draw the Party-state's legal institutions on to the centre stage of politics in the decade of the 2000s. Equipped with reconfigured political rhetoric and ideology to justify its evolving approach to law and order, the Hu Jintao-Wen Jiabao leadership, particularly from 2007 to 2012, came to be known for its 'rigid' approach to the maintenance of stability. Front and centre in this surge of public dissatisfaction with abuse of power, economic inequalities and access to justice, are the issues of labour, land, and environmental disputes. Disputes and protests in these years incarnated people's frustration with not being able to secure their social and economic rights in a society that, 
for the most part, bifurcated sharply into the urban haves and rural have-nots. Increasingly, citizens expressed anger at inequalities not just of wealth and opportunity but also of access to justice. Part One of this volume explores the politics-law-stability nexus in relation to these three types of disputes.

We begin with labour disputes and their relation to rights and stability, which is the focus and theme of Sarah Biddulph's chapter. In the last few decades, labour-related unrest has increased to the point where the Party-state sees it as posing a serious threat to social and political stability. This study on the relationship between stability and rights in the regulation of labour protests examines ways in which the Party-state agencies have interpreted and responded to this unrest. Biddulph argues that the upsurge in labourrelated protests can be seen as a problem of both rights and stability. While a number of legal reforms and administrative measures have sought to improve labour stability through addressing failings in the current regulatory regime, other disturbances are interpreted to have greater political risk. Some start out as a form of rightful resistance, but later develop more political overtones. Violent protest can quickly be characterised as a social order 'emergency' requiring more direct and coercive intervention. She argues that despite some reforms, the Party-state has been unable and unwilling to address the problems of low wages and work insecurity arising from the current economic development model and concomitant inadequacies in the labour regulatory regime.

Forced land taking by local governments for the purposes of development is one of the most prominent sources of social conflict in contemporary China. He Xin's chapter on 'hard-nail household' disputes explores the process of legal mediation in land taking cases as a relatively new type of judicial activism aimed at preventing unrest and preserving stability. Policy-makers encourage mediation as the main approach to resolving these types of disputes because it allows the dispute to be dealt with in a way that discourages or even disallows the affected party to appeal or petition against the court's decision. Mediation involves the aggrieved party voluntarily accepting the outcomes, which means that the parties involved are unlikely to appeal, petition, or complain. This mode of dispute resolution may seem, in the short-term, a positive way of 
preventing unrest, but mediation does not necessarily offer a guarantee of stability. As He Xin points out, when courts fails to support the aggrieved party in mediation, protestors often assume that the courts are 'wearing the same underwear' as the local government and developers, and tensions can escalate. Conversely, when courts acquiesce to pressure from the aggrieved party in the mediation process, it encourages other hard-nail households and others to demand justice through the court process - a situation that courts do not welcome given that, in view of the pressure they are subject to, they often find it hard to rule in favour of the aggrieved party in land taking disputes. As a result, the outcome of a case is often skewed to avoid further exacerbation of tensions, regardless of the legal merit of the cases. He Xin argues that when stability concerns replace legal procedures such as formal litigation, the authority of the courts can be undermined. He questions the sustainability of mediation as a dominant approach to the stability agenda, arguing that while it may resolve some disputes, in the long run, it weakens the institutional capacity of the courts and results in increased petitioning and resistance.

He Xin's chapter makes apparent the extent to which stability-related judicial activism has become a hallmark of politico-legal culture in China today. Following this theme, Zhang Wanhong and Ding Peng's chapter on water contamination disputes argues that in recent years judicial and governmental activism has also become prominent in rural environmental disputes. This form of activism is largely justified by China's rapidly deteriorating ecological terrain, an increasingly alarming problem that links to poor sanitation, accelerated relocation of pollution to rural areas, soil contamination, water shortages and contamination (Ma 2008). In Chapter four Zhang and Ding argue that stability-related activism is expressed most noticeably in efforts to mediate collective disputes that relate to serious infringements of regulations, endangering the lives and livelihoods of rural residents. Activism of this kind also operates through local courts and governments which aim to resolve disputes between citizens and local industry or government in a way that ensures that rural social stability is maintained, sometimes at any cost. This chapter explores these themes taking two rural areas in rural Hubei province as case studies. It documents the experiences of rural residents attempting to resolve water pollution problems that gravely affect those living in the vicinity of river- 
polluting manufacturing plants, who drink the water from the river and use it for their crops. This chapter finds that when the law is inaccessible or when courts fail to protect villagers' interests over the interests of manufacturers and developers, villagers sometimes feel forced to organise and participate in 'mass incidents'. Like the two dispute-related chapters that precede it, Chapter four argues that the only lasting foundation of stability in Chinese society is the legitimacy of the law manifest in effective judicial remedy and the protection and realisation of rights.

\section{Part Two: Creating and Sustaining Legal Frameworks}

While Part One takes legal disputes as the thematic lead, Part Two of this book encompasses a number of areas of the law that include and go beyond the issue of legal disputes. The stability imperative is nowadays embedded in a wide range of practices of administrative, legal and security organs. As such, the scope of law-related studies in Part Two of this book is broad, focusing on a variety of law and justice sites where the imperative to manage discord, disorder and dispute is central to how the law intersects with the Party-state's political agenda of stability.

This second part of the book opens with Benjamin van Rooij's reflections on the contradictory nature of legal regulation and how regulation can in itself produce instability. This chapter sets the scene for Part Two with a discussion of the problem of regulation in China today and the Party-state's fragmented approach to preventing disputes through regulation. The enforcement capacities of China's regulatory regime that seek to oversee the activities of state-owned and private enterprise are underdeveloped. Weak regulation and social instability are closely entwined in today's China, van Rooij argues. Violations of regulatory laws protecting citizens from health, ecological or financial risks are major sources of both potential and realised social unrest. The fear of unrest has made the Party-state react mercurially; at times half hearted and slow to react to regulatory infringements, and at other times obsessed in its treatment of social unrest. This chapter explores how certain characteristics of authoritarianism in China unite to shape the formation and functioning of fragmented and 'irregular' uses of regulation and how these practices can damage public trust in the law. Fear of social 
unrest-either potential or realised-plays multiple and sometimes contradictory roles in the development and functioning of regulation. Threats of unrest inform the development and revision of more stringent regulatory laws; it can lead to renewed commitment to the enforcement of regulatory law but it is more often than not, shortlived. Party and government authorities' fear of unrest creates modes of public management that are 'campaign-type' responses to high conflict situations. Arguably, campaign-style governing is not sustainable in the long-term. Responses to unrest which generate regulation through ad-hoc campaigns challenge the legitimacy of formal rational institutions and create further cause for unrest. This situation generates a fragmented cycle of unrest and extemporaneous commitment to regulation. Protests can inspire the state to respond by launching campaigns that crack down on irregularities. The stop-start and short-lived nature of government recommitments to regulation brought on public pressure to enforce regulatory law sends mixed signals to the community about the 'stability' of the law itself. It also underscores the need for local and central authorities to take regulatory law much more seriously as a legitimate state instrument for the protection of citizens and ultimately the preservation of stability in China.

He Xin's chapter in Part One which is outlined above, focuses on land taking disputes, introducing the idea of mediation's renewed dominance over litigation in settling disputes. Michael Palmer's study in Part Two expands on this theme, examining how state-society relations are mediated in administrative suits in China today. It traces the rise of mediation as a dominant practice in administrative suits. In the immediate post-Mao era, one of the most serious difficulties facing the legal reform drive was the need for legal control over the administrative powers of the state. Politico-legal authorities experimented with a system of administrative litigation (xingzheng susong) in the 1980s which was then introduced in the form of a national-level law in 1990. Originally it was a means by which citizens might more effectively challenge the actions of administrative agencies. However, as Palmer explains in Chapter six it has nowadays been transformed by judicial practice that favours mediation over litigation. Transforming the meaning of administrative litigation-and the relationship between this transformation and official policies favouring socio-political stability and 
'Harmonious Society' - is a story both significant and ongoing. Accordingly, this chapter explores two central questions: what are the nature and significance of the role of mediation in administrative litigation in the PRC, and what are the most salient current developments in this unfolding tale.

Chapter seven considers a very different and somewhat unexpected site for judicial mediation: the arena of the death penalty. Trevaskes's chapter examines the reshaping death penalty policy and practice to address issues of stability and harmony preservation. Specifically, it considers how China's Supreme People's Court (SPC) and Supreme People' Procuratorate (SPP) articulate their role in maintaining stability, exemplifying justice through the propagation of two types of model cases; 'standard cases' (dianxing anli) and 'guiding cases' (zhidao anli). The cases discussed in this chapter relate to handling of lenient death sentencing in post-2007. By examining the medium and the message of model cases, the author investigates how the socio-political role of punishment in relation to the maintenance of stability is articulated top down from the SPP and SPC, to prosecutors and judges in local jurisdictions. These cases are a key means for the SPC and SPP to advertise to judges and prosecutors in local jurisdictions, what these two top legal institutions construe as correct practice for responding to the imperatives of Stability Maintenance and Harmonious Society-building. They also exemplify how judges and prosecutors are encouraged to reconcile positive 'legal outcomes' with positive 'social outcomes' in homicide cases.

Reconciling positive legal and social outcomes was also a keen concern for the drafters of China's latest Criminal Procedure Law (2013). Crime control and due process are key imperatives which define the features of criminal justice systems worldwide. In China, these two imperatives have informed recent debates on criminal procedure reform and have been an integral part of the legislative drafting process of this newly amended law. China enacted its first Criminal Procedure Law (CPL) in 1979, and substantially revised it in 1996. Chapter eight examines the most recent reform to the CPL which was passed in 2012 and came into effect in March 2013. Here, Guo Zhiyuan explores the primary reasons for the amended Law, arguing that stability is one the most 
important goals underlying the current round of criminal procedure law reform. Concerns for stability have influenced the development of the CPL in view of the imperative to address the stability issue by balancing crime control and due process. The crime control imperative requires the criminal procedure law to punish offenders in order protect the public from social harm caused by crime. The imperative of due process, on the other hand, requires the criminal procedure law to protect the accused from the risks of wrongful proceedings and other abuses of power. Guo argues that while in theory, due process and crime control are compatible, in practice they can easily contradict each other in a context where stability becomes the overriding politico-legal standard. Rationalisation of crime control's dominance as the driving principle of the CPL is made possible given that criminal law in China is predominantly designed to protect the collective majority from the minority, a predisposition that suits the stability maintenance agenda.

Disciplinary and legal frameworks dealing with corruption and abuse of power are the subjects of Fu Hualing's chapter. One of Xi Jinping's first political statements after his ascendancy to the Party throne in November 2012 was to announce yet another anticorruption drive. Corruption is linked directly to stability and social order because, together with abuses of power, is one of the key sources of community dissatisfaction with China's governance model. Since acceding to the United Nations Convention against Corruption (UNCAC) in 2003, China has implemented a series of anti-corruption initiatives to prevent and reduce corruption and to punish corrupt officials. Fu Hualing's study introduces those initiatives in broad strokes and assesses their success and limits in containing the spread of corruption and regaining public trust. Fu's study strikes a largely positive note, arguing that for the time being, implementing the UNCAC-based international best practices in China has contributed to the nation's political stability and authoritarian resilience. In the long term, however, the one party state may not be able to offer a resolution to the prevalent and deeply entrenched corruption that reaches into every sector of government.

Murray Scot Tanner's chapter explores the law-stability nexus in relation to the 
People's Armed Police. Increasingly over the decade of the 2000s, the People's Armed Police (PAP) has been called upon to supplement the police force in breaking up large scale mass protests. In this context, the 2009 PAP Law was designed to legalise organisational control over China's paramilitary police forces, which previously had been governed primarily by military and police regulations. But the law's text-which was extensively debated within the National People's Congress Standing Committeeultimately raised as many questions about control of paramilitary forces as it answered. Tanner's chapter on changes to PAP Law examines prior organisation of control over the PAP, debates over the 2009 Law and its final text, and subsequent practices for mobilising these forces, which play an increasingly important role in China's internal security and maintenance of stability.

\section{Part three: Framing the discourses of stability}

The final part of this volume interrogates political rhetoric surrounding the stability imperative and how the prevailing political discourses in $21^{\text {st }}$ century China relate to stability. Elisa Nesossi's chapter moves the discussion from legal frameworks to the area of social management discourse and how it affects the practices of pre-trial detention in China. The chapter examines the framing of a new type of discourse, 'Social Management Innovation' in the Chinese criminal justice system, assessing how the Party-state sustains a neoliberal rhetoric on rights and justice without weakening emphasis on its leading and paternalistic role in society. Nesossi examines how typically Western concepts like transparency and accountability have been co-opted within the Chinese legal-political discourse on 'social management' and 'criminal justice socialisation' to support the line of stability and legitimacy maintenance, which helps sustain party-state leadership. She considers the place of reform in the system of pre-trial detention, and, it examines in particular the role of the procuratorate, mass organizations and the general public within detention centres.

Following Nesossi's chapter on social management in action, Sapio's study of social management theory contemplates this new discourse as a recent post-Harmonious Society political program in which stability has come to be rationalised as an imperative 
of the 'general will' of the masses. She examines the rationales behind 'Social Management Innovation' that has emerged over recent years as a new ideological phenomenon in China. Social Management Innovation began as an addendum to Stability Maintenance but has taken on a life of its own since 2010. Sapio connects Social Management Innovation rationales to Stability Maintenance by exploring the theoretical role of the 'general will' in Chinese and western political philosophy. Social Management entails selectively adapting neo-liberal governmental techniques and using them to maximise the prospects of social stability and economic growth. This development has been explained using arguments based on the 'retreat of the state' and the decline of ideology. However, as Sapio explains, politics remains supreme in this new program just as it has in the Harmonious Society and Stability Maintenance years. This chapter asks what exogenous intellectual forces have allowed such a shift in governance, and it argues that these did not envisage a different set-up of the relationship between power and the lives of individual human beings. Once translated into political praxes, such ideas have induced a continuing emphasis on stability: the undisturbed operation of the laws that regulate society, politics and the economy.

The final chapter by Trevaskes, Sapio, Biddulph and Nesossi concludes this volume by reflecting on the political context of the themes explored in the book, examining the journey to stability obsession in recent years. It explores the discursive frameworks within which China's leadership has reframed justice and security practices as a way of understanding the question of why the stability imperative came to be the Number One preoccupation of the Party-state in the decade of the 2000s. It does so by sketching the path of stability's rise to prominence through political programs and rhetoric linking stability to the national imperatives of economic development and institutional reform. The discussion concludes the book by reflecting on the erosion of public trust in the law in China, questioning the cost of the stability imperative in relation to the loss of law's credibility in recent times.

\section{Conclusion}

The Politics of Law and Stability in China examines the nexus between law, politics and stability at this crucial period in the nation's rise to the status of economic superpower. It 
explores the impact of Party-state rationales for social stability on legal reform, judicial decision-making and justice system policy relating to institutions such as courts, the People's Armed Police and detention centres and the handling of civil disputes and social unrest. This study presents politico-legal approaches the Party-state used to manage (and in some cases, punish) the behaviour of Chinese citizens as a way of responding to what it sees as destabilising or potentially destabilising social action. The chapters in this volume concern how the stability imperative has reframed approaches to law and justice practices in the decade of the 2000s and how these changes may affect the legitimacy of the law when the stability agenda overtakes routine law and justice concerns. The stability imperative challenges law's legitimacy because it requires changes in legal and justice practices that can contradicts the idea 'governing the country according to law'. Moreover, it invites excessiveness when it is interpreted at the local level especially since local governments and court workers can be penalized for not containing dissent locally.

The Party-state recognizes that over the last decade, the rise in protest, along with legal disputes, are the product of the social and economic fallout of rapid economic growth. But rather than dealing head-on with the causes of the problems, it has recast these disputes as a destabilizing and potentially dangerous to society and therefore to the Party's prospects for long-term rule. The price it now pays for this reluctance or incapacity to deal head on with structural and political weaknesses is an increasingly

disharmonious Chinese society, mistrustful of the Party's commitment to 'governing the country in accordance with the law'.

\section{References}

Bakken, Borge (2012), 'The Chinese surveillance state: the rationalities of "social management" in China'. Paper delivered at the Conference on Stability and Law, Australian National University, Canberra, 8-9 November.

Biddulph, Sarah (2007), Legal reform and administrative detention powers in China. New York: Cambridge University Press, 2007. 
Biddulph Sarah, Cooney Sean, and Ying Zhu (2012), 'Rule of law with chinese characteristics: the role of campaigns in lawmaking', Law and Policy, 34/4: 373-401.

Cai, Yongshun (2008), Local governments and the suppression of popular resistance in China' The China Quarterly 193: 24-42.

Chen, Xi (2013), 'The rising cost of stability', Journal of Democracy 24/1: 57-64.

Chen, Xi (2012), Social protest and contentious authoritarianism in China, New York: Cambridge University Press.

Dutton, Michael (1992), Policing and punishment in China: from patriarchy to the people. Cambridge: Cambridge University Press.

Fu, Hualing (2013), 'Politicized challenges, depoliticized responses: Political monitoring in China's transitions', University of Hong Kong Faculty of Law Research Paper 2013/014.

Kelly, David (2011), 'Stability and social governance', East Asia Forum 3 (2) 12-13. http://www.eastasiaforum.org/2011/09/13/stability-and-social-governance-inchina/. Accessed 15 September 2013.

Li, Lianjiang, Liu, Minxing and Kevin O’Brien (2012), 'Petitioning Beijing: the high tide of 2003-2006' China Quarterly 210: 313-34

Liebman, Benjamin L. (2012), 'Professionals and populists: the paradox of China's legal reforms', in Timothy B. Weston and Lionel M. Jensen eds. China in and beyond the headlines, Rowman and Littlefield: Lanham MD, pp. 214-230. 
Ma Tianjie (2008), 'Environmental mass incidents in rural China: examining largescale unrest in Dongyang, Zhejiang', China Environmental Series (CES10) (2008/2009): 33-56

http://www.wilsoncenter.org/sites/default/files/CES\%2010\%20Feature\%20Artic le,\%20pp.\%2033-56.pdf.,. Accessed 8 August 2013.

Mattis, Peter (2012), The foundations of china's future stability, Asia-Pacific Bulletin, No. 149, http://www.eastwestcenter.org/publications/foundation-chinas-futurestability. Accessed 30 January 2013.

Minzner, Carl (2013), 'China at the tipping point?: the turn against legal reform' Journal of Democracy 24/1: 65-72.

Tanner, Murray Scot (2007), 'Chinese communist party strategies for containing social protest', Paper delivered at $2^{\text {nd }}$ Berlin Conference on Asian Security (Berlin Group).

Tanner, Murray Scot (2012), 'Internal security' in Chris Ogden ed. Hand of China's Governance and Domestic Politics, Routledge: Florence KY, pp. 88-96.

Trevaskes, Susan (2010), Policing serious crime in China, London: Routledge.

Wang Qinghua (2013) 'Sifa xingfanghua qushi zhide shensi' (Petitionisation of justice is worthy of deeper attention) Nanduwang (Southern Daily online) 6 February 2013, http://ndnews.oeeee.com/html/201302/06/22518.html Accessed 13 February 2013.

Woo, Margaret Y. K. (2013), 'Bounded legality: China's developmental state and civil dispute resolution' Maryland Journal of International Law, 27/1: 235-262.

Yu Jianrong (2010) 'Holding tight and not letting go: the mechanisms of 'rigid 
stability', Global China 5 (2), http://www.globalasia.org/V5N2 Summer 2010/Yu Jianrong.html Accessed 13 February 2013.

Xie, Yue (2013), 'Rising central spending on public security and the dilemma facing grassroots officials in China', Journal of Current Chinese Affairs 42/2, 79-109.

Zhang, Taisu (2009), 'Zhongguoren zai xingzheng jiufenzhong weihe pianhao xingfen? (Why the Chinese Public Prefer Administrative Petitioning over Litigation) Shehuixue yanjiu (Sociological Studies) 3: 139-162.

Zhang, Taisu (2012) 'The Pragmatic court: reinterpreting the Supreme People’s Court of China', Columbia Journal of Asian Law, 25/1:61.

Zhao, Suisheng (2011), 'The China model and the authoritarian state', East Asia Forum 3/2:12-13.

http://www.eastasiaforum.org/2011/08/31/the-china-model-and-theauthoritarian-state/ Accessed 15 September 2013.

Zhou Kaili (2010) 'Sifa xinfanghua qushi yinfa danyou' (Trend in the petition-ising of justice becoming an increasing concern) Caixin, 2 December, http://china.caixin.com/2010-12-02/100203981.html. Accessed 2 July 2013.

Zhu, Suli (2010), 'Guanyu nengdong sifa yu datiaojie (On Judicial Activism and Grand Mediation), Zhongguo faxue (Legal Science in China) 1:5-16. 


\section{University Library}

\section{- M M N E R VA A gateway to Melbourne's research publications}

Minerva Access is the Institutional Repository of The University of Melbourne

Author/s:

Trevaskes, S;Nesossi, E;Sapio, F;Biddulph, S

Title:

Stability and the Law

Date:

2014

Citation:

Trevaskes, S., Nesossi, E., Sapio, F. \& Biddulph, S. (2014). Stability and the Law. Trevaskes, $S$ (Ed.). Nesossi, E (Ed.). Sapio, F (Ed.). Biddulph, S (Ed.). The Politics of Law and Stability in China, (1), pp.1-18. Edward Elgar Publishing Ltd.

Persistent Link:

http://hdl.handle.net/11343/254301 